\title{
FOREWORD BY WILLIAM J. PERRY
}

In April 2009, in the beautiful Old World capital of Prague, President Obama delivered an eloquent speech in which he made a simple but dramatic declaration: "I state clearly and with conviction America's commitment to seek the peace and security of the world without nuclear weapons."

He repeated that commitment in a speech to the UN General Assembly in September, and then introduced a resolution to the Security Council calling for steps that move toward a world without nuclear weapons. The president invited the "Gang of Four"-George Shultz, Henry Kissinger, Sam Nunn, and myself- to be part of his delegation that day, and graciously credited our two op-eds as having had an important influence on his position. Of course a world without nuclear weapons is still a distant goal, but the president's two speeches have launched us on a journey toward that goal.

Why did the four of us take such a dramatic position on nuclear weapons? What has developed since our first op-ed was published? And what is the path forward?

On the first question, I will not presume to speak for my three colleagues, but I will give you an account of how my own thinking was shaped. I have come to believe that the gravest security danger the world faces today is the detonation of a nuclear bomb in Washington or Moscow or Mumbai, and that this danger is increasing every year. But I must also acknowledge that my views on the danger of nuclear weapons have been shaped by my experiences during the Cold War. I will describe one of those experiences to you.

One night when I was the Under Secretary of Defense for Research and Engineering, I was aroused by a phone call at 3:00 a.m. As I sleepily picked up the 
phone I heard a voice identifying himself as the watch officer at NORAD. The general got right to the point, telling me that his computers were indicating 200 intercontinental ballistic missiles on the way from the Soviet Union to the United States.

I woke up immediately. The computer alert was, of course, a false alarm. The general was calling me in the hopes that I could help him determine what had gone wrong so that he had some answers when he briefed the president the next morning. That call is engraved in my memory, but it is only one of three false alarms that I know have occurred in the United States, and I don't know how many more might have occurred in the Soviet Union.

I describe this experience to make the point that the risks of a nuclear catastrophe have never been theoretical to me-I experienced those dangers at first hand.

Ironically, during the same period that I experienced the false warning of an attack by Soviet nuclear weapons, I was responsible for the development of America's nuclear weapons: the B-2 bomber, the MX missile, the Trident submarine, the Trident missile, the air-launched cruise missile (ALCM), and the Tomahawk. I saw all too clearly the risks in building such deadly weapon systems, but I believed that it was necessary to take those risks given the very real threats we faced.

However, after the Cold War ended, I believed that it was no longer necessary to take those terrible risks, and I believed that we should begin to dismantle the deadly nuclear legacy of the Cold War. My first opportunity to act on that belief came in 1994, when I was asked by President Clinton to be his secretary of defense. As secretary, my first priority was working to reduce the dangers of the Cold War nuclear arsenal.

Our greatest immediate danger was that the nuclear weapons in Ukraine, Kazakhstan, and Belarus would fall into the hands of terrorists. When the Soviet Union collapsed, these new republics had inherited the nuclear weapons on their soil. Ukraine, for example, had more nuclear weapons than the United Kingdom, France, and China combined. And the country was going through great social, economic, and political turbulence. Through adroit diplomacy we were able to get these new republics to agree to give up their nuclear weapons. Then, using the Nunn-Lugar program, we assisted them in the dismantlement process.

I personally supervised the dismantlement process in Ukraine, visiting the largest and most modern intercontinental ballistic missile (ICBM) site, at Per- 
vomaysk, four times. During my time in office I oversaw the dismantlement of about 8,00o nuclear weapons in the United States and the former Soviet Union, and helped three nations go non-nuclear: Ukraine, Kazakhstan, and Belarus. That was the first time since the dawn of the nuclear age that nuclear proliferation had been reversed.

Also in my last year in office, with the help of the national lab directors, I steered the Comprehensive Test Ban Treaty (CTBT) through the Pentagon so that President Clinton could sign it. At the time, I believed that we were well on our way to mitigating the deadly nuclear legacy of the Cold War.

Since then the effort has stalled, even reversed. The U.S. Senate rejected the ratification of CTBT. Russia and China are building a new generation of nuclear weapons. North Korea already has a small nuclear arsenal, and Iran is following in their footsteps. If we cannot contain those two latter nations, it is very likely that there will be widespread proliferation in the Middle East, and possibly in Northeast Asia as well. Additionally, Pakistan is a growing danger. The government in Pakistan is being challenged by Al Qaeda and Taliban militias in an increasingly violent insurgency. And, to add to the danger, the Pakistani government has released A. Q. Kahn.

It is not an exaggeration to say that these dangerous actions have put the world at a tipping point of proliferation. If Iran and North Korea cannot be stopped from building nuclear arsenals, I believe that we will cross that tipping point, with consequences that will be dangerous beyond most people's imagination.

I have gone through this background so that you can understand my state of mind in October 2006, when George Shultz decided to hold a workshop at Stanford on the twentieth anniversary of the Reykjavik Summit meeting between presidents Reagan and Gorbachev. Reagan was considered to be a hawkish president, but his views on nuclear weapons were far from hawkish, as expressed in his statement: "A nuclear war cannot be won and must never be fought." To the surprise of many of his own supporters, he really believed what he said. And at the Reykjavik Summit he seriously explored with Gorbachev the idea of moving toward the elimination of nuclear weapons and ballistic missiles, the key weapons of the Cold War.

The two presidents actually came close to an agreement but in the end backed away. Those of you who remember that summit meeting will also remember that most political and academic specialists were incredulous that the two presidents would even discuss such a rash idea. But twenty years later, at 
the Stanford workshop, we concluded that we ought to revive the idea that Reagan and Gorbachev discussed at that summit, moving toward a world without nuclear weapons.

We believed that some really dramatic action was needed to stop this terrible drift to a nuclear catastrophe, and our two op-eds, in January of 2007 and January of 2008, prescribed such dramatic actions. We did not expect much more from our first op-ed than the usual responsive articles from academics in this field, so the actual reaction caught us by surprise.

We were swamped with news articles and letters from colleagues, mostly of the view that the world was overdue for a serious reevaluation of nuclear arsenals and postures. Buoyed by this response, we scheduled meetings with senior government officials and former officials in the United States, Russia, China, India, Japan, the United Kingdom, Italy, and Norway.

In parallel with our actions, groups of former officials in other countries also began working to move toward a world without nuclear weapons. Other groups of four were established in Germany and the United Kingdom. Bruce Blair and Barry Blechman formed a group called "Global Zero." But such unofficial activities can only go so far-the actions that make a real difference must be taken by governments.

The first indication that our op-eds were taken seriously by governments came in late 2008 with a speech by Margaret Beckett, who was the United Kingdom's foreign minister. During the presidential campaign in 2008 both candidates, Senator McCain and Senator Obama, expressed qualified support. So we ended 2008 with more response and more support than we had truly expected, but, in fact, no real governmental action.

Then in 2009, some truly unprecedented actions were taken by governments. Just ten weeks after he was inaugurated, President Obama made his famous speech in Prague, from which I quoted at the beginning of this foreword. At their April 2009 bilateral in London, President Obama and President Medvedev jointly declared their support for a world without nuclear weapons. That was followed by their summit meeting in Moscow, at which both presidents made a commitment to move forward to a new arms reduction treaty by the end of the year, and President Obama said that he would work for a Fissile Material Cut-Off Treaty (FMCT) and the ratification of CTBT. At that time, several prominent Americans across the political spectrum stepped forward to call for a world without nuclear weapons, including General Colin Powell and Governor Arnold Schwarzenegger. 
And governments all over the world weighed in. British prime minister Gordon Brown officially endorsed moving to a world without nuclear weapons, and the United Kingdom is taking the lead in research on the supportive verification technology. Norway, Italy, and Finland each have sponsored conferences on nuclear disarmament and are funding non-proliferation projects. Japan and Australia formed an International Commission on Nuclear Non-Proliferation and Disarmament, of which I was the American commissioner. In December of 2009, the commission held its fourth and final meeting in Hiroshima.

The commissioners agreed on recommendations that spell out a three-phase plan of action. The first phase deals with the near-term actions on START, CTBT, and FMCT, as well as curtailing the nuclear programs of Iran and North Korea. The commissioners call for that phase to be completed by 2012 .

The second phase is no less daunting. It calls for the United States and Russia to dismantle their 22,000 nuclear weapons at a rate of 1,500 per year until they are down to a level of 500 each, while other nations hold or decrease their arsenals. The commission called this new level the "minimization point." This second phase will necessarily entail a high level of verification of the weapons dismantlement and the associated fissile material. Remember that to date we have never verified the removal of warheads, only delivery vehicles. The commissioners estimate that the nuclear powers could reach this "minimization point" by 2025. At that point the world would take a deep breath and see if the geopolitical conditions at the time permit moving to zero.

The third and final phase, which entails moving to zero, would require a different geopolitical environment than now exists. It is possible, of course, that the process of dismantlement and verification in the second phase would itself promote the trust and confidence that would help build such an environment.

So this past year we have seen unprecedented actions and planning that none of us could have predicted at the beginning of the year. It truly has been an Annus Mirabilis, a "Year of Miracles."

That term has been used to describe two different miraculous years in science: 1666 , when Newton published his landmark papers on the theory of gravitation and optics; and 1905, when Einstein published three landmark papers, including his famous paper on the theory of relativity. In my lifetime, I can remember Vaclav Havel calling 1989 an Annus Mirabilis as all of the Eastern European nations gained their independence, nearly bloodlessly. And of course that year culminated with the fall of the Berlin Wall.

I do not mean to suggest that the developments of this year are equal in 
significance to those remarkable events, but considering my expectations going into 2009, I must say that I consider the developments of that year as nothing short of miraculous.

Which brings me to my last question and to this book. What remains to be done is much, much more difficult than what has been done. In the next two years, for example, the United States and Russia need to ratify the New START. The United States needs to ratify the CTBT. The international community needs to negotiate a new FMCT. The international community needs to find a way to stop nuclear weapons programs in North Korea and Iran. And the nuclear powers need to start making significant annual reductions in their nuclear weapons arsenals, to be sustained for more than a decade.

These are daunting challenges. None of them will be achieved with business as usual; indeed, their achievement will call for brilliant diplomacy sustained over many years.

Getting to Nuclear Zero examines some of the key issues that will need to be addressed. More important, authors from different countries explore these issues from an international perspective. It is clear that international cooperation is required to be successful in realizing the vision that so many now embrace. This book greatly contributes to the international discussion of the steps required and the obstacles to overcome if we are to make progress on the path to a world free of nuclear weapons.

Palo Alto, California, Spring 2010 
Getting to Zero 
